\title{
Compressive Strength Determination of Granite Dust-Sandcrete
}

\author{
Ihemegbulem Ezekiel $\mathrm{O}^{1 *}$, Njoku Kelechi $\mathrm{O}^{1}$, Nwokorobia Godfrey $\mathrm{C}^{1}$, Ikpa Patience $\mathrm{N}^{1}$
}

${ }^{1}$ Civil Engineering Department @ Federal University of Technology, Owerri, Nigeria

DOI: $10.36348 /$ sjce.2022.v06i01.002

| Received: 26.11.2021 | Accepted: 02.01.2022 | Published: 12.01.2022

*Corresponding author: Ihemegbulem Ezekiel O

Civil Engineering Department @ Federal University of Technology, Owerri, Nigeria

\section{Abstract}

This study entails the research data of the empirical study carried out on the compressive strength determination of Granite dust-Sandcrete with granite dust as partial replacement of three (3) grades of river sand with fineness modulus (fm) of 2.29, 2.44 and 2.89. The percentage replacements range from $0 \%, 10 \%, 20 \%, 30 \%, 40 \%, 50 \%$ to $100 \%$. A gross number of 102 cubes of $150 \times 150 \times 150 \mathrm{~mm}$ square metallic mould were blend, mixed and cast with a mix ratio of 1:5. Three (3) cubes were blend, mixed and cast for each percentage partial replacement and a total 34 cubes for each grade of river sand, were crushed to derive the compression strength of 28th day curing respectively. For river sand with fineness modulus of 2.29 , the highest strength was recorded on $80 \%$ replacement, while the least strength was recorded on $0 \%$ replacement. For the same river sand, compressive strength increased from $0 \%$ to $80 \%$ and assumed a descending trend from $80 \%$ to $100 \%$. For 2.44 fineness modulus, the highest strength was recorded on $80 \%$ replacement, while the least strength was recorded on $0 \%$ replacement. Also, for the same river sand, compressive strength increased from $0 \%$ to $80 \%$ and assumed a descending trend from $80 \%$ to $100 \%$. For river sand of 2.89 fineness modulus, the highest strength was recorded on $70 \%$ replacement, while the least strength was recorded on $0 \%$ replacement. Also, compressive strength increased from $0 \%$ to $70 \%$ and assumed a descending trend from $70 \%$ to $100 \%$. Generally, the compressive strength assumed an upward trend as the percentage replacement increases.

Keywords: Compressive Strength, Dust-Sandcrete.

Copyright $($ ) 2022 The Author(s): This is an open-access article distributed under the terms of the Creative Commons Attribution 4.0 International License (CC BY-NC 4.0) which permits unrestricted use, distribution, and reproduction in any medium for non-commercial use provided the original author and source are credited.

\section{INTRODUCTION}

In recent times, sand, cement and granite has taken the centre stage in the construction industry. In the same vein, the construction sector world has been in earnest revolution in the continual usage of conventional concrete materials in civil works of sandquarry dust as a building material in construction industries [9]. Amidst the economic crisis and global economic pandemic, the conventional construction materials have been found to be increasingly exorbitant and unaffordable for low income earners [3].

Various studies and researches has been geared towards determining the suitable materials that can partially or totally replace concrete materials such as river sand and cement and equally cut the cost of concrete productions[5]. A lot of funds and experimental efforts have been channelled towards achieving this feat. This gave rise to the development of river sand mix with various low cost materials and cement mix with various low cost materials and as well ascertaining their suitability and structural performance and standards. In same vein, the physical properties of such low cost materials are ascertained to categorise and grade them according to structural standards [7].

Granite dust as a bye product of granite crushing has been proven to meet require structural specifications a concrete constituent material. Studies has shown that Granite dust can serve as fine aggregate in higher concrete grades and coarse aggregate in lightweight concrete grades.

In similar trend, a lot of studies have been have carried out to ascertain the effect of these alternative materials with the structural properties such as compression strength of the concrete produced from such materials. Also, the effect of the partial replacement of such materials for sand on the structural characteristics of the concrete [10].

In conclusion, a lot of work has been done for year in bid to find an alternative to ameliorate the utility quantum of conventional concrete component materials 
Ihemegbulem Ezekiel O et al., Saudi J Civ Eng, Jan, 2022; 6(1): 9-13

[1]. This is so achieved by employing partial or total replacement of several alternative bye products which were found to pass the structural and physical standards. These alternative bye-materials must be affordable, available and easy to source in the current economic weather [2].

This is a bid to foster their adoption and ameliorate the excessive use overuse of the material (river sand) and the incessant depletion of river bank deposits [8]. Therefore, it is suitable to utilise cheap, environmental-friendly alternative materials for cement and river sand that are preferably bye-products [6]. Granite dust has presented itself as structurally and physically suitable as a partial substitute to river sand, added to its structural benefits and contribution to the overall sample sandcrete[4]. In recent times, Granite dust has been employed for various civil works in the construction sector such as highway pavement, production of civil work materials such as light weight aggregates, bricks and marbles.

In this study, the focal point is to determine the variational model between the compressive strength of the cube and that of the percentage replacements.

\section{MATERIALS AND METHODS \\ 2.1 CEMENT}

OPC cement otherwise known as Ordinary Portland Cement from the Ashaka Portland Cement Company, Ashaka, Gombe state of Nigeria with their chemical characteristics in line with british standard.

\subsection{Water}

A potable, colourless, odourless and tasteless potable water that was utilised for this study. It was free from debris, synthetic matter and other contaminates. The water was sourced from ground water within the catchment of Owerri city, Imo state, Nigeria.

\subsection{River sand}

River sand devoid of silt, debris, clay, grease and any chemo-organic substances. The river sands were sourced from Nwaorie River, located at in Owerri municipal, Imo State, Nigeria.

The three grades of river sands utilised in this study had specific gravity of $2.5,2.55$ and 2.72 respectively; mean bulk density of $0.92 \mathrm{~g} / \mathrm{ml}, 0.95 \mathrm{~g} / \mathrm{ml}$ and $0.98 \mathrm{~g} / \mathrm{ml}$ respectively; fineness modulus of 2.28 , 2.44 and 2.89; the percentage mean water absorption were $2.17 \%, 2.07$ and $2.04 \%$ and mean moisture content of $0.90 \%, 0.89 \%$ and $0.91 \%$. The coefficient of uniformity of the sand was 2.0, 2.2 and 3.0.

\subsection{Granite fines}

The granite fines or dusts were gotten from the Quarry site located at Lokpanta in Okigwe Local government in Imo State of Nigeria. The specific gravity of the granite fines was 2.6; bulk density of $0.81 \mathrm{~g} / \mathrm{ml}$; percentage water absorption of $2.54 \%$; fineness modulus of 3.57 and the average moisture content was $0.44 \%$. The coefficient of uniformity of the granite fines was 11.2.

\subsection{Metallic cube mould}

The cube mould utilised for casting is a metallic mould with a measuring $150 \times 150 \times 150 \mathrm{~mm}$.

\subsection{Physical analyses of materials}

The constituent sandcrete elements employed in this study were analysed to ascertain the following physical behaviours: sieve analysis, bulk unit weight, specific gravity, and water absorption percentage.

\section{6 granite dust-sandcrete cube production}

A total of 102 sandcrete cube samples with size of $150 \times 150 \times 150 \mathrm{~mm}$ were cast for this study using a partial replacement of granite fines of 0percent, $10 \%$, $20 \%, 30 \%, 40 \%, 50 \%$ to $100 \%$. The mix ratio used is $1: 5$ and water - cement ratio of 0.4 and 0.5 respectively. The procedural steps involved in the production of the cube samples are stated as below:

i. Determine the sundried granite dust, cement, and water and river sand with the aid of mechanical weighing balance in line with the stipulated blend ratios of 1:5.

ii. Batch each component material by weight in line with the stipulated blend ratio to give about 3 cubes for each percentage replacement.

iii. Blend all the weighed components aggregates in a container.

iv. Spray the weighed water on the blend materials using a shovel to achieve the proper homogenous mix. Then reweigh the mixed mortar.

v. Prepare the cube mould by cleaning and rubbing the internal wall surface with grease.

vi. Pour the weighed mix uniformly and in layers. Apply pressure to compact it into the metallic mould using a metallic rammer for about 20times until the mixture reaches its maximum density while in the mould.

vii. Allow the fresh sandcrete specimen remain in mould for $24 \mathrm{hrs}$ and demould it carefully, to be cured for 28days by emersing them in a curing tank.

viii. The same procedure was repeated for the other replacement of $0 \%, 10 \%, 20 \%, 30 \%, 40 \%$ to $100 \%$ respectively.

\section{RESULTS AND DISCUSSION}

The results of this study are presented on Table 1a to Table 2c and Figure 1 to Figure 3. Table 1a and Table 1b show Mix proportion for Granite dustSandcrete mix. 
Table-1a: Mix proportion for Granite dust-Sandcrete mix

\begin{tabular}{|l|l|l|l|l|l|l|}
\hline \% Replacement & $\mathbf{0} \%$ & $\mathbf{1 0} \%$ & $\mathbf{2 0} \%$ & $\mathbf{3 0} \%$ & $\mathbf{4 0} \%$ & $\mathbf{5 0} \%$ \\
\hline Blend Ratio & $0.5: 1: 5$ & $0.5: 1: 5$ & $0.5: 1: 5$ & $0.55: 1: 5$ & $0.55: 1: 5$ & $0.55: 1: 5$ \\
\hline Water(kg) & 0.26 & 0.26 & 0.26 & 0.28 & 0.28 & 0.28 \\
\hline Cement(kg) & 0.43 & 0.43 & 0.43 & 0.43 & 0.43 & 0.43 \\
\hline Aggregate(kg) & 2.1 & 2.1 & 2.1 & 2.08 & 2.08 & 2.08 \\
\hline River Sand(kg) & 2.1 & 1.9 & 1.7 & 1.49 & 1.28 & 1.09 \\
\hline Granite dust(kg) & 0 & 0.3 & 0.5 & 0.69 & 0.89 & 1.09 \\
\hline
\end{tabular}

Table-1b: Mix proportion for Granite dust-Sandcrete mix

\begin{tabular}{|l|l|l|l|l|l|}
\hline \% replacement & $\mathbf{6 0} \%$ & $\mathbf{7 0} \%$ & $\mathbf{8 0} \%$ & $\mathbf{9 0 \%}$ & $\mathbf{1 0 0} \%$ \\
\hline Blend Ratio & $0.55: 1: 5$ & $0.6: 1: 5$ & $0.6: 1: 5$ & $0.6: 1: 5$ & $0.6: 1: 5$ \\
\hline Water(kg) & 0.28 & 0.3 & 0.3 & 0.3 & 0.3 \\
\hline Cement(kg) & 0.43 & 0.43 & 0.43 & 0.43 & 0.43 \\
\hline Aggregate(kg) & 2.08 & 2.1 & 2.1 & 2.1 & 2.1 \\
\hline River Sand(kg) & 0.86 & 0.7 & 0.5 & 0.3 & 2.1 \\
\hline Granite dust(kg) & 1.28 & 1.5 & 1.7 & 1.9 & 2.1 \\
\hline
\end{tabular}

Table 2a, Table $2 \mathrm{~b}$ and Table $2 \mathrm{c}$ shows Compressive Strength Result of Granite dust-Sandcrete mix with river sand of fineness modulus of $2.29,2.44 \&$ 2.89 respectively.

Table-2a: 28th day Compressive Strength Result of Granite dust-Sandcrete mix Cubes with river sand of 2.29 fineness modulus

\begin{tabular}{|l|l|l|l|l|}
\hline $\begin{array}{l}\text { \% } \\
\text { Replacement }\end{array}$ & Average Weight(kg) & Average failure Load(N) & Area $\left(\mathbf{m m}^{\mathbf{2}}\right)$ & $\begin{array}{l}\text { Compressive } \\
\text { Strength(N/mm }\end{array}$ \\
\hline $0 \%$ & 2.5 & 122666.7 & 22500 & 5.45185156 \\
\hline $10 \%$ & 2.5 & 143333.3 & 22500 & 6.37036978 \\
\hline $20 \%$ & 2.5 & 149333.3 & 22500 & 6.63703644 \\
\hline $30 \%$ & 2.5 & 157333.3 & 22500 & 6.99259289 \\
\hline $40 \%$ & 2.51 & 161333.3 & 22500 & 7.17036978 \\
\hline $50 \%$ & 2.52 & 162666.7 & 22500 & 7.22962933 \\
\hline $60 \%$ & 2.49 & 166666.7 & 22500 & 7.40740711 \\
\hline $70 \%$ & 2.46 & 170666.7 & 22500 & 7.58518489 \\
\hline $80 \%$ & 2.45 & 174666.7 & 22500 & 7.76296267 \\
\hline $90 \%$ & 2.44 & 165880 & 22500 & 7.37244444 \\
\hline $100 \%$ & 2.47 & 163880 & 22500 & 7.28355556 \\
\hline
\end{tabular}

Table-2b: 28th day Compressive Strength Result of Granite dust-Sandcrete mix with river sand of 2.44 fineness modulus

\begin{tabular}{|l|l|l|l|l|}
\hline $\begin{array}{l}\% \\
\text { Replacement }\end{array}$ & $\begin{array}{l}\text { Average } \\
\text { Weight(kg) }\end{array}$ & $\begin{array}{l}\text { Average failure } \\
\text { Load(N) }\end{array}$ & Area $\left(\mathbf{m m}^{\mathbf{2}}\right)$ & $\begin{array}{l}\text { Compressive } \\
\left.\text { Strength(N/mm } \mathbf{m}^{\mathbf{2}}\right)\end{array}$ \\
\hline $0 \%$ & 2.64 & 140000 & 22500 & 6.22222222 \\
\hline $10 \%$ & 2.64 & 162667 & 22500 & 7.22962933 \\
\hline $20 \%$ & 2.51 & 172667 & 22500 & 7.67407378 \\
\hline $30 \%$ & 2.54 & 182000 & 22500 & 8.08888889 \\
\hline $40 \%$ & 2.6 & 198533 & 22500 & 8.82370311 \\
\hline $50 \%$ & 2.7 & 218667 & 22500 & 9.71851822 \\
\hline $60 \%$ & 2.7 & 234800 & 22500 & 10.4355556 \\
\hline $70 \%$ & 2.65 & 276667 & 22500 & 12.296296 \\
\hline $80 \%$ & 2.5 & 317333 & 22500 & 14.103704 \\
\hline $90 \%$ & 2.5 & 251280 & 22500 & 11.168 \\
\hline $100 \%$ & 2.6 & 210667 & 22500 & 9.36296267 \\
\hline
\end{tabular}


Ihemegbulem Ezekiel O et al., Saudi J Civ Eng, Jan, 2022; 6(1): 9-13

Table-2c: 28th day Compressive Strength Result of Granite dust-Sandcrete mix with river sand of 2.89 fineness modulus

\begin{tabular}{|l|l|l|l|l|}
\hline$\%$ Replacement & $\begin{array}{l}\text { Average } \\
\text { Weight(kg) }\end{array}$ & $\begin{array}{l}\text { Average failure } \\
\text { Load(N) }\end{array}$ & $\mathbf{A r e a}\left(\mathbf{m m}^{\mathbf{2}}\right)$ & $\begin{array}{l}\text { Compressive } \\
\left.\text { Strength(N/mm } \mathbf{m}^{\mathbf{2}}\right)\end{array}$ \\
\hline $0 \%$ & 2.35 & 116000 & 22500 & 5.15555556 \\
\hline $10 \%$ & 2.25 & 124000 & 22500 & 5.51111111 \\
\hline $20 \%$ & 2.26 & 132666.7 & 22500 & 5.896296 \\
\hline $30 \%$ & 2.25 & 142800 & 22500 & 6.34666667 \\
\hline $40 \%$ & 2.3 & 148666.7 & 22500 & 6.60740711 \\
\hline $50 \%$ & 2.25 & 156000 & 22500 & 6.93333333 \\
\hline $60 \%$ & 2.36 & 158666.7 & 22500 & 7.05185156 \\
\hline $70 \%$ & 2.35 & 219200 & 22500 & 9.74222222 \\
\hline $80 \%$ & 2.3 & 188666.7 & 22500 & 8.38518489 \\
\hline $90 \%$ & 2.2 & 194666.7 & 22500 & 8.65185156 \\
\hline $100 \%$ & 2.38 & 170666.7 & 22500 & 7.58518489 \\
\hline
\end{tabular}

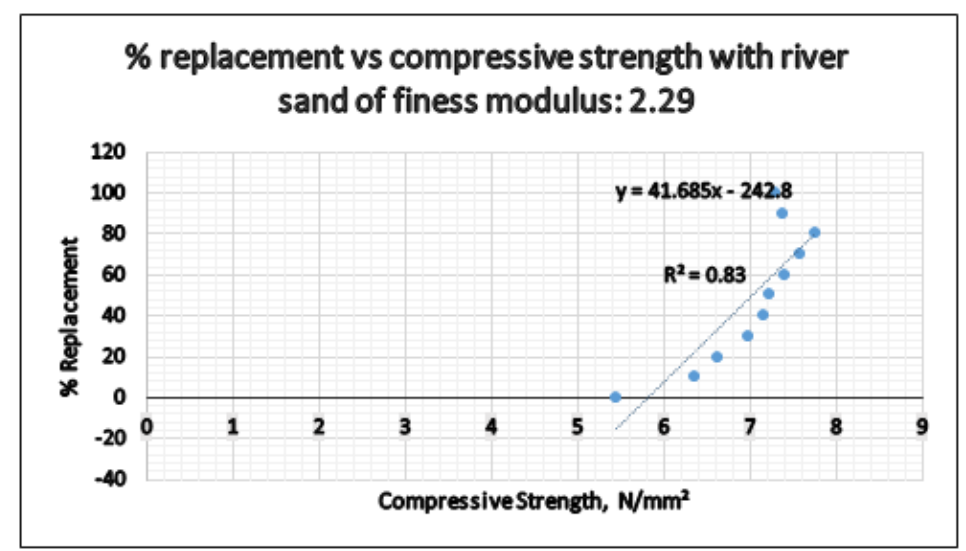

Fig-1: Mathematical Relationship between compressive strength and percentage replacement for finess modulus of 2.29

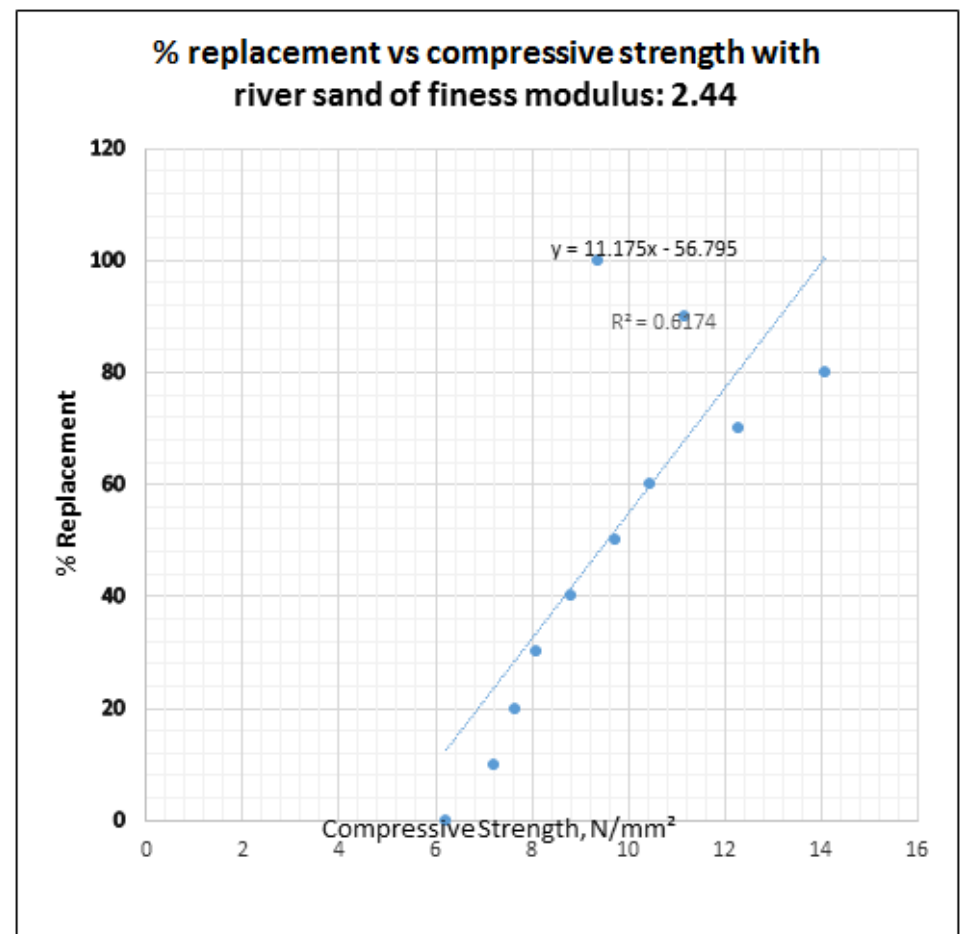

Fig-2: Mathematical Relationship between compressive strength and percentage replacement for finess modulus of 2.44 


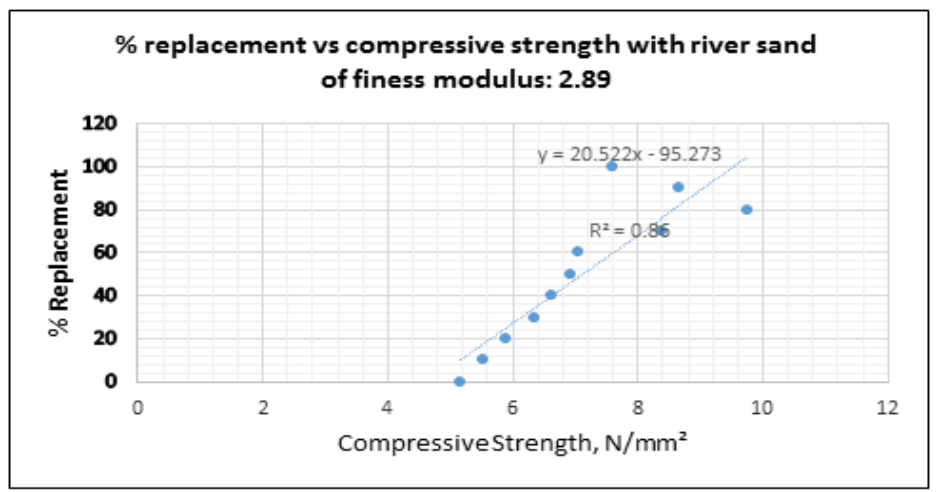

Fig-3: Mathematical Relationship between compressive strength and percentage replacement for finess modulus of 2.89

\section{DISCUSSION OF RESULT}

Table 1a and Table 1b shows Mix proportion for Granite dust-Sandcrete mix respectively using a blend ratio of 1:5 for using river sand of $2.29,2.44$ and 2.89 fineness modulus respectively. Table $2 \mathrm{a}$ and shows the results of the compressive strength of Granite dust-Sandcrete mix with river sand of 2.29 fineness modulus. Table $2 \mathrm{~b}$ shows the results of the compressive strength of Granite dust-Sandcrete mix with river sand of 2.44 fineness modulus. Table $2 \mathrm{c}$ shows the results of the compressive strength of Granite dust-Sandcrete mix with river sand of 2.89 fineness modulus.

Figure 1 shows the linear mathematical relationship between percentage replacement and compressive strength of Granite dust-Sandcrete mix with river sand of 2.29 fineness modulus. Also, figure 2 shows the linear mathematical relationship between percentage replacement and compressive strength of Granite dust-Sandcrete mix with river sand of 2.44 fineness modulus. Lastly, shows the linear mathematical relationship between percentage replacement and compressive strength of Granite dustSandcrete mix with river sand of 2.89 fineness modulus. From the linear graph, the correlation model was obtained as: $\mathrm{y}=41.685 \mathrm{x}-242.8 \mathrm{y}=11.175 \mathrm{x}-$ 56.795 and $\mathrm{y}=20.52 \mathrm{x}-95.27$ for fineness modulus of $2.29,2.44 \& 2.89$ respectively. The linear coefficient was $0.83,0.81$ and 0.86 for the linear model of the percentage replacement and that of compressive strength for the 3 river sands respectively.

\section{CONCLUSION}

From Table 2a, the highest strength was recorded on $80 \%$ replacement, while the least strength was recorded on $0 \%$ replacement. From the same Table 2a, compressive strength increased from $0 \%$ to $80 \%$ and assumed a descending trend from $80 \%$ to $100 \%$. From the Table $2 \mathrm{~b}$, the highest strength was recorded on $80 \%$ replacement, while the least strength was recorded on $0 \%$ replacement. Also, in line with Table $2 b$, compressive strength increased from $0 \%$ to $80 \%$ and assumed a descending trend from $80 \%$ to $100 \%$. From the Table $2 \mathrm{c}$, the highest strength was recorded on $70 \%$ replacement, while the least strength was recorded on $0 \%$ replacement. Also, in line with Table 2c, compressive strength increased from $0 \%$ to $70 \%$ and assumed a descending trend from $70 \%$ to $100 \%$. Generally, from Figure 1, Figure $2 \&$ Figure 3, the compressive strength assumed an upward trend as the percentage replacement increases.

\section{REFERENCES}

1. Anselem, F. (1993). Statistics of Model Analysis. The American Statisticians, 27, 17-20.

2. Banbra, R. (2013). Effect of Clay grains in sandcrete mix. International Journal of Civil and Structural Engineering 1(no.4):823-874.

3. Cornel, F. (2001). Measurement, Uncertainty, Calibration and Probability. The Statistics of Scientific and Industrial Measurement, 2,366.

4. Hartcode, K. (2002). An empirical study of Gully walls. International Journal of Engineering, Science and Technology, 135.

5. Joseph, O. (2002). Compression Strenght of Lateritic Sand and Quarry Dust Sandcrete. ARPN Journal of Engineering and Applied Science, 9(1); $77-87$.

6. Lotani, T., \& Dankah, K. (2009). Best Use of Granite fine as alternative Replacement of Sand in Concrete. International Journal of Applied Sciences and Engineering Research, 1; 391- 404.

7. NIS 97. (2014). Specifications for sandcrete mix. Annual Bulletin for Nigerian Industrial Standards.

8. Kenneth, O., \& Okere, F. (2017). Granite Dust Improvement of Nsugbe Laterite. Global Journal of Engineering Technology: 122-154.

9. Ramatan, R. (2020). Utilisation of "Quarry Dust" and "Fly Ash" as partial replacement for sandcrete blend. International Journal of Engineering Science Research, 2, 213-230.

10. Sivakumar, \& Prakash, M. (2012). Structural Characteristics of Quarry Dust application on regular sandcrete. Journal of Civil Engineering and Construction Technology, 2; 202-227. 